\title{
- ВПРОВАДЖЕННЯ ФЛЕШМОБУ В НАВЧАЛЬНИЙ ПРОЦЕС ПІДГОТОВКИ СПЕЦІАЛІСТА ГАЛУЗІ КУЛЬТУРИ І МИСТЕЦТВА (НА ПРИКЛАДІ ОСВІТНЬОГО ДОСВІДУ КИЇВСЬКОГО НАЦІОНАЛЬНОГО УНІВЕРСИТЕТУ КУЛЬТУРИ І МИСТЕЦТВ)
}

\author{
- Кириленко Катерина Михайлівна \\ - Доктор педагогічних наук, доцент, \\ ORCID: 0000-0002-3303-3947, e-mail: kf919@ukr.net, \\ Київський національний університет культури і мистецтв, \\ вул. Є. Коновальця, 36, Київ, Україна, 01133
}

\section{- Для цитування:}

Кириленко, К.М. (2020). Впровадження флешмобу в навчальний процес підготовки спеціаліста галузі культури і мистецтва (на прикладі освітнього досвіду Київського національного університету культури і мистецтв). Питання культурології, (36), 239-249. doi: https://doi. org/10.31866/2410-1311.36.2020.221071.

\section{- Анотація}

Мета статті - з'ясувати дидактичні можливості флешмобу в процесі викладання загальногуманітарних дисциплін у закладах вищої освіти культурно-мистецького спрямування та ознайомлення з освітнім досвідом Київського національного університету культури і мистецтв (КНУКіМ) з впровадження фрлешмобів в навчальний процес. У статті висвітлено багаторічний досвід апробації фрлешмобів на лекціях з дисципліни «Філософія» в КНУКіМ та представлені результати його проведення. Використовуються такі методи дослідження, як: педагогічне спостереження, педагогічний експеримент, аналіз, синтез, узагальнення, а також синектика, елементи аксіоматичного та гіпотетико-дедуктивного методів. Наукова новизна дослідження полягає у висвітленні авторського досвіду роботи та в аналізі його результатів. Висновки. Аналіз практичного досвіду засвідчує доцільність впровадження в освітній процес підготовки спеціалістів за спеціальностями даної галузі не лише сучасних технологій навчання, але й форм та методів культурно-мистецького середовища. Продемонстровано використання потенціалу фрлешмобу формувати нові звички, включати значну кількість студентів в змістовну діяльність. З'ясовано, що впровадження фрлешмобів як творчих методів роботи в процесі викладання загальногуманітарних дисциплін у вищій школі дозволяє зацікавити та вмотивувати студентів; стимулювати розвиток творчих здібностей; активізувати пізнавальну діяльність; спрямувати викладання непрофільних дисциплін у сфреру професійних інтересів та у площину особистісних пошуків студента; мотивувати молодь до формування активної світоглядної та громадянської позиції; залучити студента до творення інноваційного освітнього середовища.

Ключові слова: фрлешмоб; лекція; творчі завдання; інноваційне освітнє середовище; навчальний досвід КНУКіМ 


\section{- Вступ}

Культурно-мистецькі практики, що активно розвиваються нині, не лише створюють зростаючий попит на культурно-мистецьку діяльність у суспільстві, але й актуалізують проблему підготовки спеціаліста у сфері культури, який би був здатний як творити ці нові культурно-мистецькі фрорми, так і вміти їх аналізувати. Навчання спеціаліста у галузі культури і мистецтва повинно резонувати із запитами суспільства на оновлення як освітніх, так і культурно-мистецьких змістів. У освітній процес підготовки фахівців за спеціальностями даної галузі потрібно якнайширше впроваджувати не лише сучасні технології навчання, але й форми та методи культурно-мистецького середовища. Потужній освітній потенціал у закладах вищої освіти культурно-мистецького спрямування має фрлешмоб про його успішне впровадження в навчальний процес свідчить досвід Київського національного університету культури і мистецтв (далі - КНУКіМ) останнього десятиріччя.

Підґрунтя всебічного аналізу світоглядно-теоретичного та мистецько-культурного аспекту флешмобу заклав американський соціолог та письменник Говард Рейнгольд у своїх творах «Віртуальне товариство» (1993) і «Розумний натовп: наступна соціальна революція» (2006). Флешмоби були предметом вивчення значної кількості науковців і досліджувалися в різних аспектах. Так М. Афронін (2013), розглянувши флешмоб як тип взаємодії в міській спільноті, описав певні принципи його організації. Флешмоб як новий тип комунікації досліджували О. Копієвська (2015), Т. Купрій та М. Головко (2012), М. Пашкевич (2018). К. Станіславська (2016), А. Крилова (2013), Н. Мусієнко (2010) аналізували фрлешмоб як сучасну мистецько-видовищну форму, як перформанс. $€$ дослідження фрлешмобу як різновиду інтернет-культури та мережевого суспільства (Щербина, 2005), як форми соціальної та політичної взаємодії (Олещук, 2015), як ігрової стратегії (Чайка, 2010).

Втім, дидактичні можливості флешмобу та його навчальний потенціал в контексті викладання гуманітарних дисциплін у закладах вищої освіти не були предметом окремого вивчення.

\section{- Мета статті}

Висвітлення дидактичних можливостей флешмобу в процесі вивчення загальногуманітарних дисциплін у закладах вищої освіти культурно-мистецького спрямування та ознайомлення з освітнім досвідом КНУКіМ з впровадження фрлешмобів в навчальний процес, зокрема в рамках проведення лекції, що $€$ найбільш поширеною формою організації навчального процесу у вищій школі.

\section{- Виклад матеріалу дослідження}

Як зазначають дослідники, фрлешмоб (від англ. flash-mob - «миттєвий натовп») - це «вид короткострокової вуличної акції, що ініційована та проводиться, зазвичай, мережевими користувачами» (Кириленко, 2018). Важливими рисами фрлешмобу є попередня скоординованість учасників та заздалегідь визначена їх роль у дійстві, відсутність керівника, що жорстко регламентує сценарій, імпровізованість та спонтанність в процесі проведення, мобільність, нетривалість 
дії, яка має несподіване місце проведення, чітко визначений початок та кінець, у якій беруть участь усі флешмобери водночас, деяка абсурдність того, що відбувається щодо місця і дії, відсутність будь-яких додаткових мотивів (економічного, релігійного, політичного тощо характеру). Флешмоб є спланованою дією, яка має відбуватися спонтанно.

Флешмоб є різновидом мистецтва дії чи акціонізму, іншими відомими фоормами якого $є$ хепенінг та перформанс. Метою акціонізму було продемонструвати умовність та відсутність відмінностей між життям та мистецтвом, нагальність створення митцем не завершених статичних фрорм, а живого мистецького продукту, що творить сам себе. Мета проведення фрлешмобів найрізноманітніша: розважитися, отримати яскраві чи гострі відчуття, відрізнитися від інших, вразити, порушити звичний хід життя (як свого, так і оточуючих), подолати стереотипні моделі поведінки, відчути свою причетність до певного середовища чи до певної ідеї, отримати заряд енергії, емоційне розвантаження (Пашкевич, 2018). За будь-яких обставин, флешмоб активізує та мобілізує його учасників, долаючи звичний хід їхнього життя.

Навчальний процес в закладах вищої освіти попри постійно зростаючі наміри його урізноманітнити і модернізувати тяжіє до визначеності, регламентованості, плановості та інших виявів системності. Це своїм наслідком має деяке збайдужіння та розчарування студентів як учасників навчального процесу. Привернути їх увагу до процесу навчання, зацікавити змістом навчального процесу, зорієнтувати його вивчення у сферу особистісних пошуків, стимулювати розвиток творчих здібностей, залучити студента до творення інноваційного освітнього середовища, - ці та інші можливості надає впровадження в освітнє середовище фрлешмобів.

Флешмоби як різновиди імпровізованих акцій неодноразово проводилися студентами, що засвідчує наявний у них інтерес до подібних акцій (Поплавський, 2001). До прикладу, в КНУКіМ традиційно проводяться флешмоби, зорганізовані студентським парламентом на підтримку соборності України та єдності українського народу (https://www.youtube.com/watch?v=tbFLc-FnJis), до Дня української хустки (http://fmm.knukim.edu.ua/novini-fakultetu/2026-fleshmob-do-svyataukrajinskoji-khustki.html), до Дня вишиванки (http://knukim.edu.ua/vsesvitniy-denvishivanki/) та ін.

Флешмоби у КНУКіМ впроваджуються й у навчальний процес. Дидактичні можливості флешмобів вивчалися автором протягом останніх десяти років та вже висвітлювалися у науковій періодиці (Кириленко, 2016). Безперечно, флешмоби як частина новітніх методів навчання не $є$ буквальним відтворенням фрлешмобів як явищ суспільно-політичного та культурно-мистецького життя (Кириленко, 2016). Флешмоби є різновидом творчих завдань, виконати які пропонується студентам за власним бажанням в рамках опанування навчальної програми з певної дисципліни. Такі завдання викликають неприхований інтерес, у тому числі навчальний, як у студентів, що радо відгукуються на їх виконання, так і у тих, що їх ігнорують. Творчі завдання мають на меті стимулювати у студента такий ракурс вивчення навчального матеріалу, який передбачає його особисте опрацювання, що супроводжується продукуванням власних ідей. 
У рамках викладання дисципліни «Філософрія» (у кількості 4 кредитів загальним обсягом 120 год) на другому курсі підготовки бакалаврів студентам КНУКіМ автор пропонує до виконання наступні творчі завдання: 1) зобразити найбільш філософрську букву української абетки та написати есе, що пояснює свій вибір; 2) підібрати символ однієї з культурно-фрілософрських парадигм («захід» або «схід») та аргументувати свій вибір; 3) віднайти річ чи предмет, що могли би бути новітніми креативними символами української культури та репрезентували б одну з головних іï̈ рис і розтлумачити свій символ; 4) намалювати колір істини та пояснити свій вибір. Попередньо студентам пояснюється, що есе - це невеликий за обсягом прозовий твір, який висловлює власні думки, враження автора, має довільно вибрану фрорму та не претендує на вичерпне розкриття теми. Свої роботи студенти презентують на лекціях, показ робіт відбувається у формі фрлешмобу, правила проведення якого передбачають, що всі, хто бажає взяти участь, мають на початку чи наприкінці заняття разом в аудиторії продемонструвати свою роботу, а далі по черзі її коротко пояснити. Есе, які пишуть студенти, часто мають поетичну форму, що засвідчує високий творчий потенціал студентської аудиторії, а також готовність з її боку до творчого інноваційного навчання.

Протягом 2010-2015 років на різних фракультетах КНУКіМ тривав наступний проєкт: в процесі вивчення курсу «Філософрія» студенти брали участь в інтелектуальному фрлешмобі на тему: «Найбільш філософська буква української абетки». Вони писали короткі філософські есе, які супроводжували творчими роботами: малюнками, аплікаціями, витинанками, що виконувалися у найрізноманітніших техніках. Результатом цього творчого проєкту стала книга «Філософрська абетка: арт-формат» (Філософоська абетка: арт-формат / авт. ідеї та упоряд. К. Кириленко. Київ : Агентство «Україна», 2016. 80 с. : іл.), яка була підготовлена до друку кафедрою філософії спільно з кафедрою графічного дизайну і реклами КНУКіМ та надрукована 2016 року. Презентація книги, а також виставка творчих робіт студентів, що увійшли до неї, та тих робіт, які були написані вже після ії завершення, відбулася в читальній залі Наукової бібліотеки КНУКіМ у квітні 2016 (http://knukim.edu.ua/filosofska-abetka-art-format/). Книга має 80 сторінок, на яких представлені 220 малюнків, 216 студентських есе та 197 робіт студентів різних факультетів університету: кіно і телебачення, дизайну та реклами, журналістики і міжнародних відносин, готельно-ресторанного і туристичного бізнесу, хореографрічного мистецтва. Дане видання не лише фріналізувало п'ятиріччя студентських роздумів над фрілософрією літери, але й стало логічним продовженням іншої книги (Філософська абетка : креативно-інновац. навч. посіб. / авт. та упоряд. К. М. Кириленко. Київ : Агентство «Україна», 2015. 144 с.), що є словником фрілософрських термінів, який був написаний викладачем та креативно поданий студенткою (http://knukim.edu.ua/novunu/filosofska-abetka-2/). Якщо перша книга презентує усталені фрілософські терміни та поняття, то друге видання - це результат творення студентами власних смислів у результаті їх роздумів над філософрською проблематикою. Автором дизайну книги «Філософрська абетка: арт-фрормат» $є$ голова секції плакату та графічного дизайну Київської організації Національної спілки художників України (КОНСХУ), кандидат мистецтвознав- 
ства, старший викладач кафедри графічного дизайну КНУКіМ А. Будник. Книга вийшла друком у рік 130-річчя від дня народження відомого українського графіка Георгія Нарбута та містить на своїх сторінках його малюнки з серії «Українська абетка» (цікаво, що дотепер більш повного передруку «Української абетки» Нарбута 1917 року в одному виданні не було). Малюнки відомого графріка та студентів створюють на сторінках книги неповторний діалог як мистецьких технік, так і фрілософських сенсів.

Виконання даного творчого завдання мало великий відгук серед студентів, про що вони розповідали на презентації книги, з цікавістю відшукуючи на її сторінках власні роботи. Ідея роздумів над змістом літери надихнула студентів та викладачів на створення ще ряду книг, зокрема: «Людина - це...» (Людина це... : інновац. навч. посіб. / авт. ідеї та упоряд. К. Кириленко. Київ : Вид. центр КНУКіМ, 2019. 108 с.), електронна книга «АРТ-абетка» (http://kf.knukim.edu. ua/52-art-abetka.html), до яких увійшли роботи студентів, що не були представлені у першій книзі або були створені після її видання.

Флешмоб «Філософрія літери» відбувається і нині на лекційних заняттях з філософії, творчі роботи студентів експонуються на виставці поряд з приміщенням кафедри фрілософрії і педагогіки КНУКіМ.

Інший фрлешмоб під назвою «Захід чи Схід» відбувається на лекціях із фрілософії в рамках ознайомлення із темою «Західна та східна парадигми фрілософування». Студентам пропонується принести річ, що символізує той тип культури, який їх цікавить більше, і пояснити свій вибір. Презентувати можна лише один символ, який презентує один із зазначених типів культури, що передбачає попереднє ознайомлення студентів з характеристиками цих парадигм за навчальною літературою та визначення щодо опрацьованого матеріалу. За результатами фолешмобу в аудиторії викладач з'ясовує кількісну пропорцію зацікавлених у східній чи західній культурі та має можливість відповідно до цього акцентувати більшу увагу на тій частині навчального матеріалу лекції, який цікавить аудиторію найбільше. Принагідно студентам пропонується подумати над приналежністю української культури до тієї чи іншої культурної парадигми. Слід зазначити, що кількість студентів, які зацікавлені сходом, зростає з року в рік. Власне, це і було однією з причин проведення серії навчально-методичних семінарів кафедрою фрілософії КНУКіМ спільно з кафедрою історії фрілософіії фрілософрського фракультету Київського національного університету імені Тараса Шевченка за участі Надзвичайного і Повноважного Посла Індії в Україні пана Маноджа Кумара Бхарті.

Результати даного флешмобу були презентовані на першому науковометодичному семінарі «Індійська фрілософрія: наука чи релігія», що відбувся 28 вересня 2017 року в Київському національному університеті імені Тараса Шевченка за участі студентів та викладачів КНУКіМ (http://knukim.edu.ua/ indiyska-filosofiya-nauka-chi-religiya-2/). За результатами роботи семінару було опубліковано науково-методичний (Філософія індійської культури : наук.-метод. посіб. інновац. типу / авт.-упоряд.: Т. Кононенко, К. Кириленко, Г. Гнатовська, А. Кирієнко, Г. Кулініч, Д. Овдієнко ; за заг. ред. Т. Кононенка. Київ : Агентство «Україна», 2019. 260 с.) та навчальний посібники (Індійська фрілософія : посіб. 
для студентів вищих навч. закл. / авт.-упоряд.: Т. Кононенко, К. Кириленко, Г. Гнатовська, А. Кирієнко, Г. Кулініч, Д. Овдієнко ; за заг. ред. Т. Кононенка. Київ : Фоліо, 2019. 144 с.). Зазначені видання містять висвітлення проведення даного фрлешмобу в аудиторії та презентують аналіз його результатів.

Ще одним прикладом навчального флешмобу, який діє в рамках викладання фрілософії у КНУКіМ, є фрлешмоб «Символи української духовності». Його мета привернути увагу студентів до роздумів над особливостями української ментальності і до визначення ключового, на їх думку, символу української культури. Свій вибір студенти супроводжують демонстрацією того чи іншого символу, який вони попередньо підбирають та приносять на лекційне заняття, а також озвученими та записаними аргументами, що розтлумачують його. Специфіка завдання полягає у тому, щоб віднайти річ чи предмет, що могли би бути новітніми креативними символами української культури. Лекція на тему «Особливості української фрілософії» розпочинається із навчального фрлешмобу, який заздалегідь анонсується студентам на попередній парі. Цей фрлешмоб проходить протягом десяти років на різних потоках. Типовими символами в аудиторіях є: вишиті сорочки, у яких студенти приходять на лекцію, намиста, віночки, народні сукні та хустки, зустрічаються і досить несподівані символи, як-то: шабля (як символ перманентної необхідності самозахисту), паспорт громадянина України (як символ державності), банківська картка (як символ економічної спроможності та світового визнання), фрукти та гілочки дерев (як символ людові до світу та життя у гармонії із природою та всесвітом), і навіть люстерко, власне зображення у якому студентка супроводила коментарем «Я - це і є Україна!». Наприкінці фрлешмобу викладач підсумовує аргументи, які наводять студенти, і разом із ними складає словесний портрет української ментальності, ґрунтуючись на якому висвітлює характерні риси української фрілософії. Такий вид роботи, по-перше, зорієнтовує студента на сприйняття теоретичного матеріалу, який викладається на лекції; по-друге, стимулює до попередніх роздумів над тематикою лекції та самовизначення в темі, яка буде висвітлюватися на парі, до формування світоглядних принципів та переконань, до формування громадянської позиції; по-третє, зацікавлює аудиторію у аналізі теоретичного матеріалу лекції шляхом пошуку у матеріалі, який висвітлюється викладачем, впізнаваних, прийнятних чи, навпаки, неприйнятних для власних переконань аргументів.

Викладання фрілософії у КНУКіМ має ще один цікавий дидактичний аспект: розробка курсу лекцій у фрорматі презентацій. Даний фрормат курсу має на меті не лише залучити до викладання гуманітарної дисципліни можливості технічних засобів навчання, але й розробити такий формат подачі лекцій з відповідним навчально-методичним забезпеченням, за якого кожна лекція позиціюється як представлення (презентація) певної теми з навчальної програми курсу. Формат презентації дозволяє повною мірою впровадити міждисциплінарний підхід до вивчення дисципліни, за якого філософія тієї чи іншої епохи постає як сплетіння культурно-мистецького пошуку окремої доби, а вивчення окремих фрілософських тем супроводжується їх висвітленням суміжними дисциплінами. Студенти, що вивчають курс фрілософії у такому форматі, можуть легко відновити лекційний матеріал на сторінках посібника, який є частиною навчально- 
методичного комплексу та представлений як у друкованому, так і у електронному варіанті (Кириленко К. Філософія: наука і культура : мультидисциплінар. навч. посіб. Київ, 2014. 216 с.). Потенціал лекційного курсу у вигляді презентацій повноцінно розкривається із залученням цих матеріалів, які у достатній кількості знаходяться в Науковій бібліотеці КНУКіМ (http://knukim.edu.ua/eksklyuzivniypidruchnik-yevropeyskogo-zrazka/).

У рамках презентації лекційної теми «Гносеологія як розділ філософії» студентам, враховуючи наявність зазначених матеріалів, пропонується взяти участь у навчальному фрлешмобі «Колір істини». Завдання для флешмоберів полягає у тому, щоб принести річ чи предмет того кольору, який на їх думку, можна назвати кольором істини і аргументувати свій вибір. Високий творчий потенціал студентів дозволяє уникнути шаблонності та одноманітності у виконанні поставленого завдання. Кольори, які студенти презентують як кольори істини, мають широку палітру: це і різні відтінки синього, і жовтий, і зелений, і білий, і навіть червоний. Студенти приносять речі побутового вжитку, аксесуари одягу, листки кольорового чи білого паперу, вбираються самі в певну кольорову гаму тощо. Наприкінці флешмобу викладач знайомить студентів із традиційним для наукової літератури (за Ф. Порталем) потрактуванням кольору істини та пропонує вивчення теми у формі презентації, яка має не лише блакитно-синю кольорову гаму подачі матеріалу, але й супроводжується демонстрацією підібраних у відповідній кольоровій гамі репродукцій картин імпресіоністів. Імпресіонізм як течія та напрям у мистецтві пропагує фріксацію вражень та появу співпереживань, це, своєю чергою, стимулює студентів як до пошуку власного трактування проблематики істини, шляхів, методів та результатів її пошуку, так і до фрормування власних думок щодо наскрізних фрілософських відповідей на ключові питання гносеології. Такий формат викладання дозволяє не лише встановити міжпредметні зв'язки фрілософії з іншими дисциплінами, зокрема, культурологією та мистецтвознавством, але й візуалізувати їх.

Результати описаних фрлешмобів регулярно висвітлюються на сайті кафедри фрілософії і педагогіки КНУКІМ (http://kf.knukim.edu.ua/) та на сторінці кафедри в Instagram (https://www.instagram.com/kaf_philosophy/).

\section{- Висновки}

Флешмоби мають не лише соціокультурний, але й потужний навчальний потенціал. Впровадження флешмобів як творчих методів роботи в процесі викладання загальногуманітарних дисциплін, зокрема, на лекції як найбільш розповсюдженій формі організації навчального процесу у вищій школі, дозволяє: 1) привернути увагу студентів до процесу навчання; 2) зацікавити їх у предметному наповненні дисципліни; 3) стимулювати розвиток творчих здібностей молоді; 4) активізувати пізнавальну діяльність студента під час проведення лекційних занять; 5) викладання загальногуманітарних дисциплін адаптувати до сорери професійних інтересів аудиторії; 6) зорієнтувати викладання у площину особистісних пошуків студента; 7) стимулювати у студента процес самовизначення, формування власних думок та поглядів; 8) мотивувати молодь до фрормування активної громадянської позиції; 9) залучити студента до творення 
інноваційного освітнього середовища; 10) закласти підвалини формування освітньої концепції оосвіта впродовж життя». Особливо доречним $є$ використання дидактичного потенціалу флешмобів в роботі зі студентами закладів вищої освіти культурно-мистецького спрямування в процесі викладання дисциплін загальногуманітарного змісту. Досвід КНУКіМ з впровадження флешмобів у навчальний процес може бути використаний та вдосконалений у інших закладах вищої освіти. Предметом подальшого вивчення науковців та практиків може стати аналіз навчальних можливостей фрлешмобів в контексті впровадження засад дуальної освіти на творчих спеціальностях у закладах вищої освіти.

\section{- Список використаних джерел}

Афонин, М.В. (2013). Флешмоб как тип взаимодействия в городском сообществе. Вестник социально-политический наук, 12, 14-18.

Кириленко, К. (Ред.). (2018). Філософрія культури. Словник. Агентство "Україна".

Кириленко, К.М.(2016). Концептуальні засади викладання фрілософії як непрофрільної дисципліни у вищому навчальному закладі. Гілея: науковий вісник, 105(2), 285-290.

Копієвська, О. Р. (2015). Флешмоб як соціокультурне явище. В Культурологічний альманах (Вип. 1: Ціннісні зміни молоді та сучасні форми культуротворчості, с. 70-72). Нілан-ЛТД.

Крылова, А. В. (2013). Флешмоб и иные способы активизации массового потребления музыкальных форм искусства. Проблемы музыкальной науки, 1(12), $42-45$.

Купрій, Т. Г., \& Головко, М. Ю. (2012). Флешмоб як соціальне явище і технологія інформаційної комунікації. Грані, 7, 71-75.

Мyсієнко, Н. (2010). Public art у просторі сучасного міста: київська практика. Сучасні проблеми дослідження, реставрації та збереження культурної спадщини, 7, $136-149$.

Олещук, П. М. (2015). Вплив соціальних мереж на протестну політичну мобілізацію. Гілея: науковий вісник, 93, 311-314.

Пашкевич, М. (2018). Флешмоб як новий тип сучасної перформансної комунікації. Бібліотекознавство. Документознавство. Інформологія, 3, 111-117.

Поплавський, М. М. (2001). Шоу-бізнес: теорія, історія, практика. Видавництво КНУКіМ.

Рейнгольд, Г. (2006). Умная толпа: новая социальная революция (А. Гарькавый, Пер.). ФАИР ПРЕСС.

Станіславська, К. І. (2016). Мистецько-видовищні форми сучасної культури [Монографія] (2-е вид.). Національна академія керівних кадрів культури і мистецтв.

Чайка, І. Ю. (2010). Особливості ігрових проявів у життєдіяльності сучасного суспільства. Грані, 2(70), 103-107.

Щербина, В. (2005). Соціальні риси мережних спільнот. Соціальна психологія, 2, 139-149.

Rheingold, H. (1993). The Virtual Community: Homesteading on the Electronic Frontier. http:// www.rheingold.com/vc/book/intro.html.

\section{- References}

Afonin, M. V. (2013). Fleshmob kak tip vzaimodeistviya v gorodskom soobshchestve [Flash mob as a type of interaction in the urban community]. Vestnik sotsial'no-politicheskii nauk, 12, 14-18 [in Russian]. 
Chaika, I. Yu. (2010). Osoblyvosti ihrovykh proiaviv u zhyttiediialnosti suchasnoho suspilstva [Features of game manifestations in the life of modern society]. Hrani, 2(70), 103-107 [in Ukrainian].

Kopiievska, O. R. (2015). Fleshmob yak sotsiokulturne yavyshche [Flash mob as a sociocultural phenomenon]. In Culturological Almanac (Iss. 1: Tsinnisni zminy molodi ta suchasni formy kulturo tvorchosti [Value changes of youth and modern forms of cultural creativity], pp. 70-72). Nilan-LTD [in Ukrainian].

Krylova, A. V. (2013). Fleshmob i inye sposoby aktivizatsii massovogo potrebleniya muzykal'nykh form iskusstva [Flash mob and other ways to activate the mass consumption of musical art forms]. Problemy muzykal'noi nauki, 1(12), 42-45 [in Russian].

Kuprii, T. H., \& Holovko, M. Yu. (2012). Fleshmob yak sotsialne yavyshche i tekhnolohiia informatsiinoi komunikatsii [Flashmob as a social phenomenon and information communication technology]. Hrani, 7, 71-75 [in Ukrainian].

Kyrylenko, K. (Ed.). (2018). Filosofiia kultury [Philosophy of culture]. Dictionary. Ahentstvo "Ukraine" [in Ukrainian].

Kyrylenko, K. M. (2016). Kontseptualni zasady vykladannia filosofii yak neprofilnoi dystsypliny $\mathrm{u}$ vyshchomu navchalnomu zakladi [Conceptual principles of teaching philosophy as a non-core discipline in higher education]. Hileia: naukovyi visnyk, 105(2), 285-290 [in Ukrainian].

Musiienko, N. (2010). Public art u prostori suchasnoho mista: kyivska praktyka [Public art in the space of a modern city: Kyiv practice]. Suchasni problemy doslidzhennia, restavratsii ta zberezhennia kulturnoi spadshchyny, 7, 136-149 [in Ukrainian].

Oleshchuk, P. M. (2015). Vplyv sotsialnykh merezh na protestnu politychnu mobilizatsiiu [The influence of social networks on protest political mobilization]. Hileia: naukovyi visnyk, 93, 311-314 [in Ukrainian].

Pashkevych, M. (2018). Fleshmob yak novyi typ suchasnoi performansnoi komunikatsii [Flashmob as a new type of modern performance communication]. Library Science. Record Studies. Informology, 3, 111-117 [in Ukrainian].

Poplavskyi, M. M. (2001). Shou-biznes: teoriia, istoriia, praktyka [Show business: theory, history, practice]. Vydavnytstvo KNUKiM [in Ukrainian].

Rheingold, H. (1993). The Virtual Community: Homesteading on the Electronic Frontier. http:// www.rheingold.com/vc/book/intro.html [in English].

Rheingold, H. (2006). Umnaya tolpa: novaya sotsial'naya revolyutsiya [The smart crowd: a new social revolution] (A. Gar'kavyi, Trans.). FAIR PRESS [in Russian].

Shcherbyna, V. (2005). Sotsialni rysy merezhnykh spilnot [Social features of network communities]. Sotsialna psykholohiia, 2, 139-149 [in Ukrainian].

Stanislavska, K. I. (2016). Mystetsko-vydovyshchni formy suchasnoi kultury [Art and entertainment forms of modern culture] [Monograph] ( $2^{\text {nd }}$ ed.). National Academy of Culture and Arts Management [in Ukrainian]. 
- IMPLEMENTING A FLASHMOB METHOD FOR THE SPECIALISTS TEACHING AND TRAINING IN THE FIELD OF CULTURE AND ARTS (THE CASE OF THE KYIV NATIONAL UNIVERSITY OF CULTURE AND ARTS)

\section{- Kateryna Kyrylenko}

- Doctor of Pedagogical Sciences, Associate Professor, ORCID: 0000-0002-3303-3947, e-mail: kf919@ukr.net, Kyiv National University of Culture and Arts, Kyiv, Ukraine

\section{- Abstract}

The purpose of the article is to find out the didactic possibilities of flash mobs in the process of teaching of general humanities at higher educational establishments of cultural and artistic direction and to get acquainted with the educational experience of the Kyiv National University of Culture and Arts as to the introduction of flash mobs into the educational process. The article highlights the long-term experience of the approbation of flash mobs at lectures on the discipline of the "Philosophy" at the National University of Culture and Arts and presents the results of its implementation. The author of the article uses the following research methods: pedagogical observation, pedagogical experiment, analysis, synthesis, generalization, as well as synectics, elements of axiomatic, hypothetical and deductive methods. The scientific novelty of the article lies in the demonstration of the author's work experience and analysis of its results. Conclusions. The analysis of the practical experience has demonstrated the expediency of introducing into the educational process of the specialists training not only of modern training technologies, but also forms and methods of the cultural and artistic environment. The use of the flash mob's potential to form new habits and include a significant number of students into the meaningful activities has been shown. It has been found that the introduction of flash mobs as creative methods of work in the process of teaching of general humanities at higher educational establishments allows us to arouse student's interest and motivation; stimulate the development of creative abilities; activate cognitive activity; direct the teaching of non-core disciplines in the sphere of professional interests and personal search of the student; motivate young people to form an active worldview and citizenship; involve the students in creating an innovative educational environment.

Keywords: flash mob; lecture; creative tasks; innovative educational environment; educational experience of the Kyiv National University of Culture and Arts 


\title{
ВНЕДРЕНИЕ ФЛЕШМОБА В УЧЕБНЫЙ ПРОЦЕСС ПОДГОТОВКИ СПЕЦИАЛИСТА СФЕРЫ КУЛЬТУРЫ И ИСКУССТВА (НА ПРИМЕРЕ ОБРАЗОВАТЕЛЬНОГО ОПЫТА КИЕВСКОГО НАЦИОНАЛЬНОГО УНИВЕРСИТЕТА КУЛЬТУРЫ И ИСКУССТВ)
}

\author{
- Кириленко Екатерина Михайловна \\ - Доктор педагогических наук, доцент, \\ ORCID: 0000-0002-3303-3947, e-mail: kf919@ukr.net, \\ Киевский национальный университет культуры и искусств, \\ Киев, Украина
}

\section{- Аннотация}

Цель статьи - выяснить дидактические возможности флешмоба в процессе преподавания общегуманитарных дисциплин в высших учебных заведениях культурнохудожественного направления и ознакомление с образовательным опытом Киевского национального университета культуры и искусств (КНУКиИ) по внедрению фрлешмобов В учебный процесс. В статье освещен многолетний опыт апробации флешмобов на лекциях по дисциплине «Философия» в КНУКиИ и представлены результаты их проведения. Используются такие методы исследования, как: педагогическое наблюдение, педагогический эксперимент, анализ, синтез, обобщение, а также синектика, элементы аксиоматического и гипотетико-дедуктивного методов. Научная новизна исследования заключается в освещении авторского опыта работы и в анализе его результатов. Выводы. Анализ практического опыта свидетельствует о целесообразности внедрения в образовательный процесс при подготовке специалистов по специальностям означенной отрасли не только современных технологий обучения, но и форм и методов культурно-художественной среды. Продемонстрировано использование потенциала фрлешмоба фрормировать новые привычки, включать значительное количество студентов в содержательную деятельность. Выяснено, что внедрение флешмобов как творческих методов работы в процессе преподавания общегуманитарных дисциплин в высшей школе позволяет заинтересовать и мотивировать студентов; стимулировать развитие творческих способностей; активизировать познавательную деятельность; направить преподавание непрофильных дисциплин в сферу профессиональных интересов и в плоскость личностных поисков студента; мотивировать молодежь к формированию активной мировоззренческой и гражданской позиции; привлечь студента к созданию инновационной образовательной среды.

Ключевые слова: фрешмоб; лекция; творческие задания; инновационная образовательная среда; учебный опыт КНУКиИ 